\title{
Hardella thurjii (Gray 1831) - Crowned River Turtle
}

\author{
INDRANEIL DAS ${ }^{1}$ AND S. BHUPATHY ${ }^{2}$ \\ ${ }^{1}$ Institute of Biodiversity and Environmental Conservation, \\ Universiti Malaysia Sarawak, 94300 Kota Samarahan, Sarawak, Malaysia [idas@ibec.unimas.my]; \\ ${ }^{2}$ Sálim Ali Centre for Ornithology and Natural History, \\ Anaikatty(PO), Coimbatore 641 108, Tamil Nadu, India [bhupathy.s@gmail.com]
}

Summary. - The crowned river turtle, Hardella thurjii (Family Geoemydidae), is a large (CL to 65 cm) freshwater turtle, largely confined to lentic waters in the Indian subcontinent. The species shows extreme sexual size dimorphism, females attaining a length over three times that of the males. Only plant matter is taken by the species in some areas, but elsewhere prawn or fish may be taken, possibly as carrion. Courtship and mating take place during the summer months in northern India, and 8-19 ellipsoidal eggs may be produced. Heavy exploitation for its flesh and extensive wetland development projects are among the factors suspected to have made the turtle rare in localities where it was once common, although there is some evidence that the species is difficult to observe in the wild.

Distribution. - Bangladesh, India, Myanmar?, Nepal,Pakistan. Distributed across the northern Indian subcontinent from Pakistan to Bangladesh, and possibly in western Myanmar.

Synonymy. - Emys thuryi Gray 1830 (nomen oblitum), Emys thurjii Gray 1831, Hardella thurjii, Hardella thurjii thurjii, Emys flavonigra Lesson 1831, Clemmys thurgii Fitzinger 1835 (ex errore), Emys thurgii,Batagur thurgii,Hardella thurgii,Kachuga oldhami Gray 1869, Hardella indi Gray 1870,Hardella thurjii indi, Batagur falconeri Lydekker 1885, Batagur cautleyi Lydekker 1885, Batagur floweri Lydekker 1885, Batagur watsonii Lydekker 1886, Geoemyda pilgrimi Prasad and Satsangi 1967.

SuBSPECIES. - No subspecies are currently recognized, as no genetic or consistent morphological differences can be found between the western population from the Indus basin (for which the name Hardella indi Gray 1870, was established) and those further east.

STATUS. - IUCN 2008 Red List: Vulnerable (VU A1cd+2cd) (assessed 2000); CITES: Not Listed.

Taxonomy. - Originally described as Emys thuryi by Gray (1830), the species was renamed Emys thurjii by Gray (1831), and that name has remained in use. The species was later allocated to the genus Hardella Gray 1870. Lydekker
$(1885,1886)$ placed the species in the genus Batagur, in his monographs on the fossil turtles of India. All authors have, however, continued to recognize Hardella as a distinct genus for this species. Synonyms include Emys flavonigra

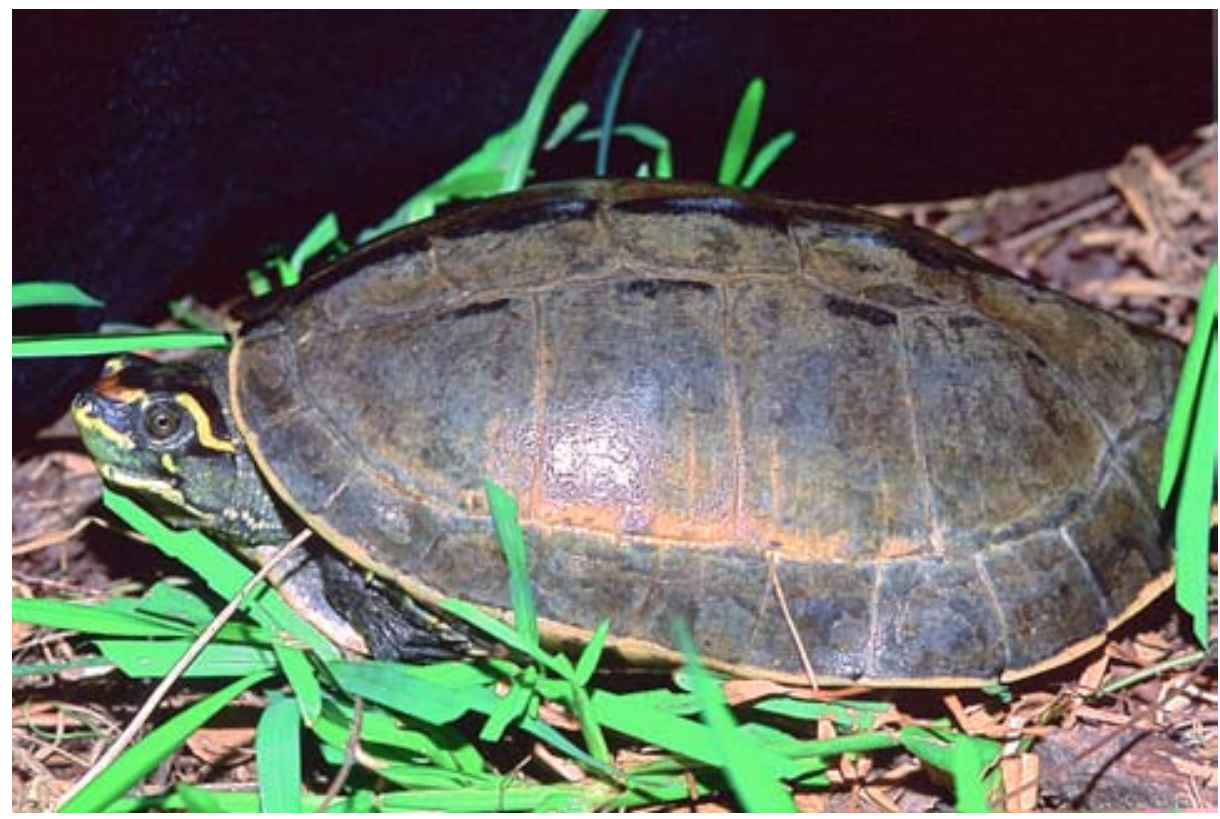

Figure 1. Hardella thurjii; adult male. National Chambal Sanctuary, Madhya Pradesh, India. Photo by Indraneil Das. 


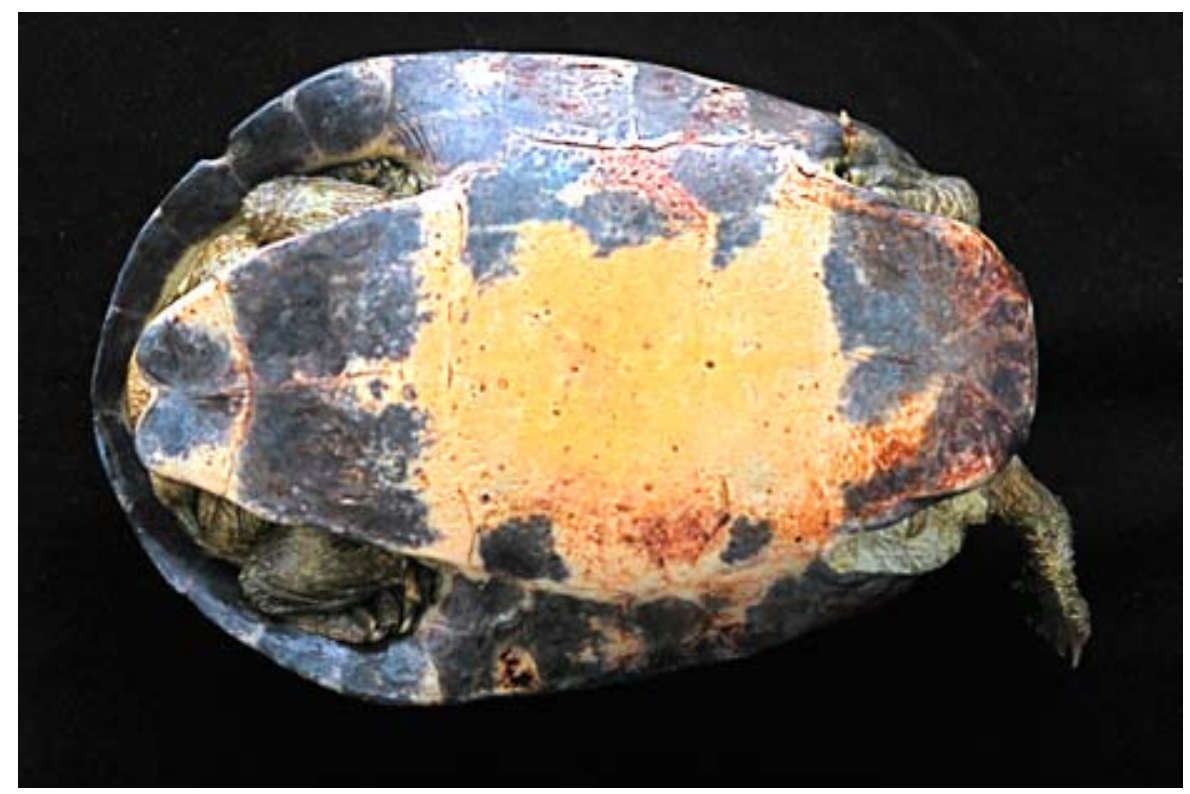

Figure 2. Hardella thurjii; adult female. Shella, Cherrapunji, Meghalaya, India. Photo by Indraneil Das.

Lesson 1831, Kachuga oldhami Gray 1869, Batagur floweri Lydekker 1885, Batagur cautleyi Lydekker 1885, and Batagur watsonii Lydekker 1886.

Hardella is recognized as distinct from other geoemydid genera, but most closely related to Pangshura, Kachuga, and Batagur, in the phylogenies presented by Spinks et al. (2004), Le et al. (2007), and Iverson et al. (2007).

Two subspecies have previously been recognized: H.t. thurjii (Gray 1831) from the Brahmaputra - Ganga drainage in the east, with a weak vertebral keel and no lateral keels, and a western subspecies H.t. indi (Gray 1870) from the Indus drainage, with a pair of weak, discontinuous lateral pleural keels, and with the region around the keels darker than the rest of the costal scutes (Das 1991). However, Praschag et al. (2007) found no evidence for genetic distinctiveness of $H$. t. indi and synonymized it under a monotypic $H$. thurjii.

A Plio-Pleistocene turtle from the Siwaliks of Haritalyanagar, Himachal Pradesh, Geoemyda pilgrimi Prasad and

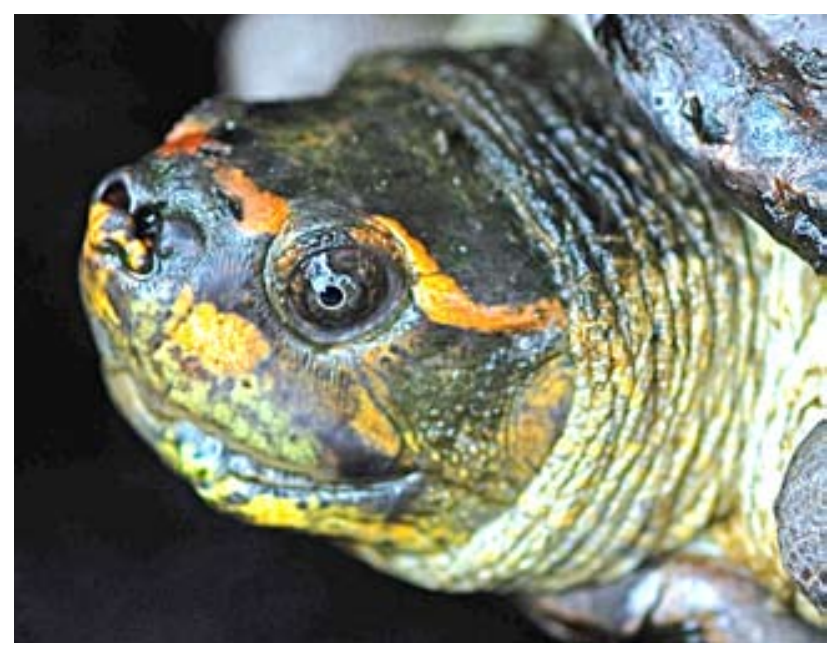

Figure 3. Hardella thurjii; adult female portrait. Shella, Cherrapunji, Meghalaya, India. Photo by Indraneil Das.
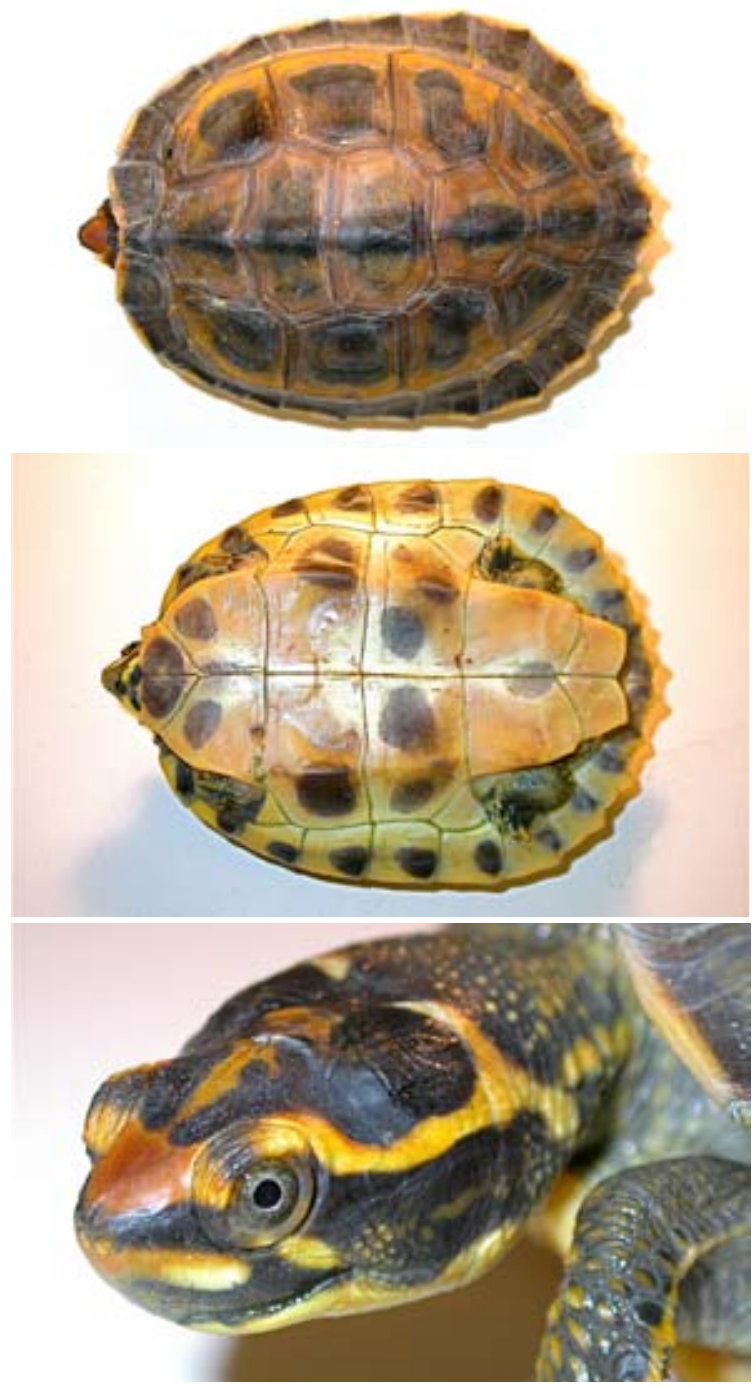

Figure 4. Hardella thurjii; juvenile. Nara Canal Gate, Khairpur, Sind Province, Pakistan. Photos by James F. Parham. 


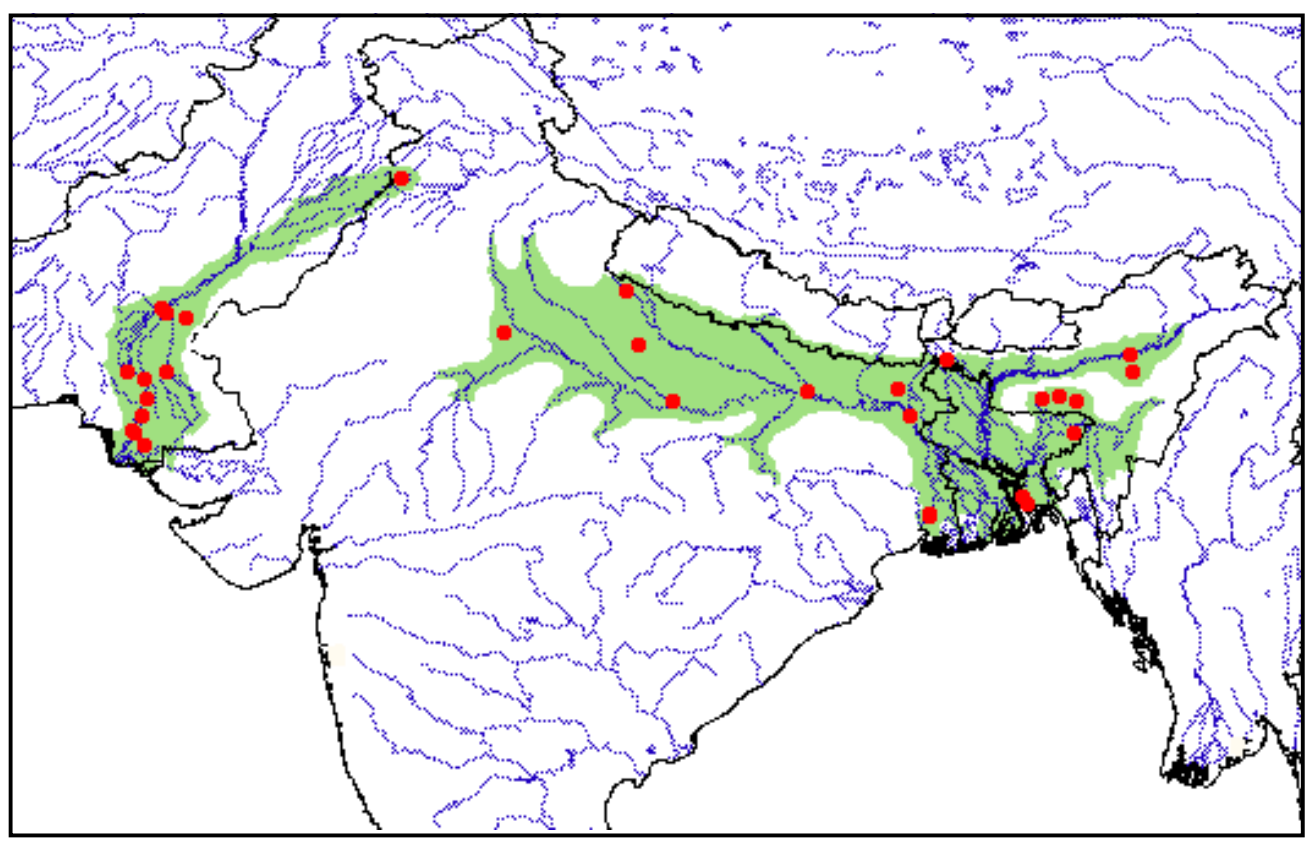

Figure 5. Distribution of Hardella thurjii in the Indian sub-continent. Red points = museum and literature occurrence records based on Iverson (1992) plus more recent and authors' data; green shading = projected distribution based on GIS-defined hydrologic unit compartments (HUCs) constructed around verified localities and then adding HUCs that connect known point localities in the same watershed or physiographic region, and similar habitats and elevations as verified HUCs (Buhlmann et al., unpubl. data), and adjusted based on authors' data.

Satsangi 1967, was shown by Das (1994) to be synonymous with Hardella thurjii, and in showing the presence of lateral keels, was assignable to the then-recognized subspecies indi. However, the type locality of the fossil turtle lies closer to the eastern Brahmaputra-Ganga distribution of the species, rather than to the western Indus distribution.

Description. - Shell thick and heavy in adults, moderately depressed, with a single weak vertebral keel in the eastern form, or a vertebral and a pair of pleural keels in the western form. The bridge is well-developed and the carapace fully sutured to the plastron, with hypertrophied buttresses that extend to the neural bones. The head is large with a projecting snout. The digits are fully webbed. Neural bones are generally hexagonal with the short sides anteriorly directed. Neurals I to IV are relatively long and narrow, but those posterior to this point are shorter and wider. The ground color of the carapace is dark brown, with gray-black keel or keels, and the costo-marginal juncture is marked with an orange-yellow band. The plastron is yellow, with a large blackish blotch on each scute. The head has four orange-yellow stripes on each side; sometimes with a short crossbar of the same color on the forehead. Limbs are brownish, with yellow edges.

Sexual size dimorphism in this species is extreme; perhaps more so than in any other geoemydid turtle, although comparable to that shown by some American emydids (Graptemys barbouri, G. pulchra). Any specimen longer than about $21 \mathrm{~cm}$ in carapace length (CL) may be identified as a female based on size alone. Males close to that size generally appear quite old, with smooth carapacial scutes and no evidence of growth annuli. Bony shells in the 15-20 cm CL range may easily be sexed by the presence of open intercostal fontanelles only in the females; these remain open in the females until a CL of at least $25-30 \mathrm{~cm}$ is reached. The tail of the male is longer and thicker than that of the female, but the adult male shows no plastral concavity, and may indeed have a slightly convex or bulbous plastron, like the females.

In India, females attain $61 \mathrm{~cm}$ in straight CL, while males reach only about a third of that length. Shrestha (1997) indicated that, in Bangladesh, females may reach as much as $65 \mathrm{~cm}$. Seven adult males from Bangladesh in the Pritchard collection (Oviedo, Florida) range in CL from 15.3-19.1 cm (average: $17.0 \mathrm{~cm}$ ). Rashid and Swingland (1997) reported that 12 Bangladesh males averaged $18.3 \mathrm{~cm}$ in CL (maximum $\mathrm{CL}=20.5 \mathrm{~cm}$ ), and $790.3 \mathrm{~g}$ in mass (maximum $1100 \mathrm{~g}$ ). Thirteen females averaged $36.2 \mathrm{~cm}$ in CL (maximum 47.2 $\mathrm{cm}$ ) and $6.3 \mathrm{~kg}$ in mass (maximum $10.5 \mathrm{~kg}$ ).

Genetics of the species has been analyzed by Praschag et al. (2007) who found no evidence of genetic distinctiveness between the two previously recognized subspecies $(H$. t. thurjii and $H$. $t$. indi) and therefore synonymized them. The karyotype is unknown.

Distribution. - The crowned river turtle is distributed over the middle and lower reaches of the northern river systems in the Indian subcontinent, comprising the Indus, Ganga, Brahmaputra, and their tributaries. The distribution of the species includes Bangladesh, northern and eastern India, Pakistan and Nepal. Shrestha (1997) described the species as "rare" in Nepal, and Schleich and Kästle (2002) could not add new records from the country. In Bangladesh, Sarker and Hossain (1997) reported the spe- 
cies as "fairly common", and mentioned the distribution as including the Padma River, Mymensingh. Rashid and Swingland (1997) described it as "common in Bangladesh", where it was found in almost all the major rivers and their tributaries, but principally in 1) the River Brahmaputra; 2) the Dholeswari in the greater districts of Mymensingh, Tangail, and Jamalpur; 3) the Kushiyara and the Surma in the greater district of Sylhet; 4) the Dakatia River, the Noakhali, the Gomoti, and the Titas in Comilla District; 5) the Dholeswari, the Burigonga, and the Sitalakkah in the greater district of Dhaka; and 6) the Kirtankhola in the Barisal District. The record from Ayeyarwady Division, Rakhine State, Myanmar (Win Maung and Win Ko Ko 2002) requires substantiation, but the species may occur peripherally in western Myanmar.

Habitat and Ecology. - The species is more or less restricted to still or slow-moving water bodies, including pools, ponds, canals and oxbow lakes (Shrestha 1997). There is, however, a report of an individual from an estuarine environment (Minton and Anderson 1962). When seasonal waterbodies dry up in Keoladeo National Park (Bharatpur), Rajasthan State, in northern India, turtles wander on land in search of new waterbodies, and may be attacked by a variety of predators, including white scavenger vultures (Neophron percnopterus), eagles, and the golden-backed jackals (Canis aureus). Occasionally, the drying mud entraps these turtles, although they may survive such conditions for up to a month, buried to a mean depth of $3.6 \mathrm{~cm}$. In Bangladesh, Sarker and Hossain (1997) reported that Hardella is found in riverine habitats, using the land along the banks and newly emerged river islands only for basking and nesting.

Minton (1966) reported only plant matter in the diet of the species, based on a single specimen he examined, although his captives also ate fruits and vegetables, one even taking parts of a frog. Rashid and Swingland (1997) examined the stomach contents of seven wild-caught Bangladesh turtles and found fragments of prawn carapace, fish bone, water hyacinth, and water weeds. Wild turtles at Bharatpur feed on grass (Paspalum distichum) and sedges (Cyperus spp.). When waterbodies dry up, turtles of this species migrate to shallow marshes and graze communally at dusk, in groups of up to 20 individuals (Bhupathy, pers. obs.).

Courtship and mating in Bharatpur occur at the height of the dry season, between April and July. Copulation takes place in shallow water (50-180 cm deep), at which time the male produces a drumming sound with his forelimbs and makes mouth-to-mouth contact with the female. Vijaya and Manna (1982) reported that sandy soil among vegetation is utilized for nesting, the turtle sometimes wandering from $50 \mathrm{~m}$ to as much as $1 \mathrm{~km}$ during the night to find a nesting site. They found a female in early January that contained 19 ellipsoidal eggs of mean dimensions 51 x $34 \mathrm{~mm}$ and mean mass of $20 \mathrm{~g}$. Khan (1987) also reported nesting at the beginning of the monsoons on sand banks of rivers in Bangladesh; although, Chaudhuri (1912) mentioned that eggs are found in the months of August and September, after the subsiding of the monsoon flooding. Rashid and Swingland (1997) considered that Hardella constituted an exception to the general rule among Bangladesh turtles that larger females showed higher fertility. Nesting occurred in winter, from November to January. The single clutch includes $12-16$ eggs; 25 eggs measured $57.9 \pm 1.05 \mathrm{~mm}$ in length, $34.1 \pm 0.78 \mathrm{~mm}$ in breadth, and had a mass of $45.2 \pm 1.36 \mathrm{~g}$ (Rashid and Swingland 1997).

Basu (1998) reported females maturing at CL 32-35 $\mathrm{cm}$ and a nesting season between late September and January, coinciding with the end of winter in Uttar Pradesh, northern India. Clutch size at this locality is in the range $8-13$, a female producing multiple clutches, resulting in 30-100 eggs being laid per season. Eggs measure 45-56 x 28-36 mm, and weigh 19-41 g. Incubation period extends between $223-273$ days (incubated between $11-36.5^{\circ} \mathrm{C}$ in translocated indoor nests), embryos suspected to show diapause. Hatchlings have CL in the range 41-46 $\mathrm{mm}$ and weigh $12-17 \mathrm{~g}$.

In Keoladeo National Park (Rajasthan, India), Vijayan (1987) found this species to be the most abundant of the seven turtle species recorded. In the course of relocation of 618 turtles from Manasarovar to a newly excavated water hole (both within the Park), 427 specimens of Hardella thurjii (69.1\% of the total) were identified. Bhupathy and Vijayan (1994) reported that aestivation duration of nine individuals averaged 32 days, and the depth of burial in the "slushy mud" averaged $3.63 \mathrm{~cm}$ to the top of the shell.

Population Status. - While no estimates of population sizes are available, Moll (1983) was informed by market vendors that the species is far less numerous in recent years, compared to former times. Javed and Hanfee (1995) noted a large population in Dudhwa National Park, northern India, near western Nepal. Choudhury and Bhupathy (1993) found only one individual in the market at Howrah, near Kolkata. In Bangladesh, this species has been reported as relatively common (Rashid and Khan 2000). Frazier and Das (1994) concluded that this species may be difficult to observe in the wild, given its wide distribution and high numbers that were earlier reported from markets, and the scarcity of field observations.

Threats to Survival. - In the 1980s, this used to be the most common hardshell turtle in the markets of eastern India and Bangladesh, favored because of its large size and palatable flesh. Heavy exploitation of the species is suspected to have contributed to its decline in recent times in India. Other factors that may affect the survival outlook of the species include the draining of wetlands for agriculture, and pollution of aquatic habitats through pesticide and fertilizer use washoff. Rashid and Khan (2000) mentioned that hatchlings are exported for the pet trade.

Conservation Measures Taken. - Few specific conservation measures have been taken, although the species occurs in several river and wetland sanctuaries in northern India, including Kaziranga National Park (Assam), Harike 
Wildlife Sanctuary (Punjab), and Keoladeo National Park (Rajasthan). Several individuals are maintained at the turtle breeding facility of the Madras Crocodile Bank Trust. The species is listed as Vulnerable on the IUCN Red List, and also listed in the Red Data Book of Nepal (Shah and Tiwari 2004).

Conservation Measures Proposed. - We recommend establishment of wetland sanctuaries in areas identified as having viable populations of the crowned river turtle within the drainage systems of all the major river systems. Such actions would benefit a vast array of other wildlife species in addition to Hardella.

Captive Husbandry. - At the Madras Crocodile Bank Trust, a small group of crowned river turtles are maintained in artificial pools, and fed on a variety of local vegetables and fruits. Highly aquatic, the turtles seldom bask, although some terrestrial activity is observed.

Current Research. - No information available. A study of the status and biology of the species is required to understand the specific conservation needs of the species.

Acknowledgments. - Supported by the Centre for Herpetology, Madras Crocodile Bank Trust, Universiti Malaysia Sarawak, Bombay Natural History Society and Sálim Ali Centre for Ornithology and Natural History. We thank Peter C.H. Pritchard for data on Hardella thurjii from his personal collection, Genevieve V.A. Gee for reading the manuscript, and James Parham for the use of photos.

\section{LITERATURE CITED}

BASU, D. 1998. Female reproductive cycle in Hardella thurjii Gray from northern India. Hamadryad 22:95-106.

Bhupathy, S. and ViJayan, V.S. 1994. Aestivation of turtles in Keoladeo National Park, Bharatpur with special reference to Lissemys punctata (Reptilia: Trionychidae). Journal of the Bombay Natural History Society 91:398-402.

Chaudhuri, B.L. 1912. Aquatic tortoises of the middle Ganga and Brahmaputra. Records of the Indian Museum 7:212-214.

Choudhury, B.C. and Bhupathy, S. 1993. Turtle Trade in India. World Wide Fund for Nature- India, New Delhi, 50 pp.

DAS, I. 1991.Colour Guide to the Turtles and Tortoises of the Indian Subcontinent. R \& A Publishing, Portishead, 133 pp.

DAS, I. 1994. The identity of the Plio-Pleistocene turtle, Geoemyda pilgrimi Prasad and Satsangi, 1967 (Testudines: Cryptodira: Bataguridae). Hamadryad 19:41-46.

FITZINGER,L.J. 1835.Entwurf einer systematischen Anordnung der Schildkröten nach den Grundsätzen der natürlichen Methode.Annalen des Wiener Museums der Naturgeschichte 1:105-128.

FraZIER, J.G. AND DAS, I. 1994. 1994. Some notable records of Testudines from the Indian and Burmese Subregions. Hamadryad 19:47-66.

GraY, J.E. 1830. A Synopsis of the Species of the Class Reptilia. In: Griffith, E. (Ed.). The Animal Kingdom Arranged in Conformity with its Organization, by the Baron Cuvier, with Additional Descriptions of all the Species Hitherto Named, and of many not before Noticed. Vol. 9. Reptilia, Supplement. London: Whittaker, Treacher, and Co., 110 pp.

GraY, J.E. 1831. Synopsis Reptilum; or Short Descriptions of the Species of Reptiles. Part I.-Cataphracta. Tortoises, Crocodiles, and Enaliosaurians. Treuttel, Wurtz, and Company, London, $85 \mathrm{pp}$.
GraY, J.E. 1869. Notes on the families and genera of tortoises (Testudinidae) and on the characters afforded by the study of their skulls. Proceedings of the Zoological Society of London 1869(1):165-225.

Gray, J.E. 1870. Supplement to the Catalogue of Shield Reptiles in the Collection of the British Museum. Part I. Testudinata (Tortoises). British Museum, London, 120 pp.

Iverson, J.B., Brown, R.M.,Akre, T.S., NeAR, T.J., Le, M., ThOMSON, R.C., AND STARKEY,D.E. 2007. In search of the tree of life for turtles. In: Shaffer, H.B., FitzSimmons, N.N., Georges, A., and Rhodin,A.G.J.(Eds.). Defining Turtle Diversity: Proceedings of a Workshop on Genetics, Ethics, and Taxonomy of Freshwater Turtles and Tortoises. Chelonian Research Monographs No. 4, pp. 85-106.

Javed, S. and Hanfee, F. 1995. Freshwater turtles of Dudhwa National Park and their conservation. Hamadryad 20:21-26.

Khan, M.A.R. 1987. Bangladesher Bonnyoprani. Vol. I. Urochor o Shorishrip. Bangla Academy, Dhaka, 169 pp.

Le, M., McCord, W.P., AND Iverson, J.B. 2007. On the paraphyly of the genus Kachuga (Testudines: Geoemydidae). Molecular Phylogenetics and Evolution 45:398-404.

Lesson, R.-P. 1831. Catalogue des reptiles, qui font partie d'une collection zoologique recueillie dans l'Inde continentale ou en Afrique, et apportée en France par M.Lamare-Piquot. Catalogue dressé (Juillet 1830). Bulletin des Sciences Naturelles et de Géologie. Deuxième Partie de Bulletin Universel publié sous les auspices de Monseigneur le Dauphin, par la Société pour la Propogation des Connaissances Scientifiques et Industrielles, et sous la direction de M. de Baron de Férussac 25:119-123.

LYDEKKER, R. 1885. Indian Tertiary and Post-Tertiary Vertebrata. Siwalik and Narmada Chelonia. Memoirs of the Geological Survey of India. Palaeontologica Indica, Series 10, 3:155-208.

LYDEKKER, R. 1886. On a new emydine chelonian from the Pliocene of India. Quarterly Journal of the Geological Society 42:540-541.

Minton, S.A. 1966. A contribution to the herpetology of West Pakistan. Bulletin of the American Museum of Natural History 134:27-184.

Minton, S.A. ANDANDERSON,J.1962.Arecord of the turtle Hardella thurgi, from salt water. Herpetologica 18:126.

MoLl, E.O. 1983.A Status Survey of Freshwater Turtle Resources in India (September 1982 - June 1983) with Recommendations for Management. Report to the American Institute for Indian Studies, $26 \mathrm{pp}$.

Prasad, K.N. and Satsangi, P.P. 1967. On a new chelonian from the Siwalik beds of Himachal Pradesh. Records of the Geological Survey India 95:533-536.

Praschag, P., Hundsdörfer, A.K., And Fritz, U. 2007. Phylogeny and taxonomy of endangered South and South-east Asian freshwater turtles elucidated by mtDNA sequence variation (Testudines: Geoemydidae: Batagur, Callagur, Hardella, Kachuga, Pangshura). Zoologica Scripta 36:429-442.

Rashid, S.M.A. AND KHAN, S.M.H. 2000. Overview of turtle trade in Cambodia. In: van Dijk, P.P., Stuart, B.L., and Rhodin, A.G.J. (Eds.). Asian Turtle Trade: Proceedings of a Workshop on Conservation and Trade in Freshwater Turtles and Tortoises in Asia. Chelonian Conservation Monographs 2, pp. 77-85.

Rashid, S.M.A. and Swingland, I.R. 1997. On the ecology of some freshwater turtles in Bangladesh. In: Van Abbema, J.(Ed.). Proceedings: Conservation, Restoration, and Management of Tortoises and Turtles - An International Conference. New York Turtle and Tortoise Society, New York, pp. 225-242.

Sarker, S.U. and Hossain, M.L. 1997. Population and habitat status of freshwater turtles and tortoises of Bangladesh and their conservation aspects. In: Van Abbema, J. (Ed.). Proceedings: Conservation, Restoration, and Management of Tortoises and Turtles - An International Conference. New York Turtle and Tortoise Society, New York, NY, pp. 290-294. 
Schleich, H.H. ANd Kästle, W. 2002. Order Chelonia/Testudines (turtles: terrapins \& tortoises). In: Schleich, H.-H. and Kästle, W. (Eds.). Amphibians and Reptiles of Nepal. Biology, Systematics, Field Guide. Koeltz Scientific Books, Koenigstein, pp. 501-573.

SHAH, K.B. AND TIWARI, S. 2004. Herpetofauna of Nepal. A Conservation Companion. IUCN Nepal, Kathmandu, 237 pp.

Shrestha, T.K. 1997. Status, biology, and management of tortoises and turtles in the Himalayan foothills of Nepal. In: Van Abbema, J. (Ed.). Proceedings: Conservation, Restoration, and Management of Tortoises and Turtles - An International Conference. New York Turtle and Tortoise Society, New York, N.Y. pp. 278-286.

SPINKS,P.Q., SHAFFER,H.B., IvERSON,J.B., AND MCCORD, W.P. 2004. Phylogenetic hypothesis for the turtle family Geoemydidae. Molecular Phylogenetics and Evolution 32:164-182.

ViJaya, J. and Manna, P. 1982. A Preliminary Status Survey of Freshwater Turtles in West Bengal, India. Report to the World
Wildlife Fund- U.S, Washington, D.C., 24 pp.

VIJAYAN, V.S. 1987.Keoladeo National Park ecology study.Bombay Natural History Society, Bombay, 123 pp.

Win Maung And Win Ko Ko. 2002. Turtles and Tortoises of Myanmar. Wildlife Conservation Society (Myanmar Program), Yangon. (5), $94 \mathrm{pp}$.

\section{Citation Format for this Account:}

Das, I. AND Bhupathy, S. 2009. Hardella thurjii (Gray 1831) crowned river turtle. In: Rhodin, A.G.J., Pritchard, P.C.H., van Dijk, P.P., Saumure, R.A., Buhlmann, K.A., Iverson, J.B., and Mittermeier, R.A. (Eds.). Conservation Biology of Freshwater Turtles and Tortoises: A Compilation Project of the IUCN/SSC Tortoise and Freshwater Turtle Specialist Group. Chelonian Research Monographs No. 5, pp. 023.1023.6, doi:10.3854/crm.5.023.thurjii.v1.2009, http://www. iucn-tftsg.org/cbftt/. 